\title{
Dealing in cultural objects: a new criminal law for the UK
}

\author{
by Simon Mackenzie
}

A report on research to evaluate the impact of the Dealing in Cultural Objects (Offences) Act 2003 on the UK market and its role in the international illicit market.

$\mathrm{C}$ ultural artefacts are stolen from temples and underground sites in "source" countries. The list of source countries is long, but the most high profile cases of looting have been in respect of Egypt, Italy, Peru, Mexico, Greece, Turkey, and China. Antiquities are highly collectable for reasons both of value and of aesthetics, and there are several prominent international centres for trade, most notably London, New York, Paris, Brussels, Hong Kong, Geneva and Bangkok. The two largest market centres for the sale of antiquities, in terms of volume of trade, are New York and London. The UK is widely acknowledged to be a significant market for looted antiquities in global terms, both by way of "end point" in the chain of supply, and as a transit point for looted antiquities which will subsequently leave the country. Antiquities looted from source countries have in the past routinely traveled to London to be sold by international dealers and auction houses to other dealers, private collectors and museums.

Critics of the market suggest that this traffic continues. Source states from which looted objects are exported for sale have responded to the problem with a two-pronged legal approach: vesting legislation and export controls. "State vesting" legislation, as we will call it here, follows a similar model across many source countries: objects over a certain age, usually 100 years old, in the ground are declared to be the property of the state, making their finding and removal a theft from the state. Integral parts of national monuments are often also expressly declared to attract criminal sanction if removed. Export controls usually take the form of licence requirements. Objects of artistic or cultural interest over 100 years old should not be exported without a licence, which will be granted by the state arts or antiquities department. Despite these restrictions at source, many countries continue to report widespread looting and unauthorized export of their underground heritage.

Strategies of regulation at the demand end of the chain of supply have been thought potentially capable of achieving a sanitising effect on the market and it is under this broad philosophy of demand-reduction as applied to illicit antiquities that the Dealing in Cultural Objects (Offences) Act 2003 Act appears. The 2003 Act, an apparent attempt to confront the illicit element of the London antiquities market, was put before Parliament as a Private Member's Bill, taking effect as law on December 30, 2003. The Act in section 1 provides for a sentence on conviction on indictment of up to seven years imprisonment and/or a fine, where a person:

dishonestly deals in a cultural object that is tainted, knowing or believing that the object is tainted.

Under section 2 of the Act, a cultural object is "tainted" if it is excavated, or removed from a monument or other building or structure of historical, architectural or archaeological interest, and such excavation or removal constitutes an offence. It is stated to be immaterial whether the excavation or removal took place in the UK or elsewhere. The intended effect of this legislation is therefore to criminalise (and by implication deter) the knowing possession or trade in the UK of antiquities looted either here or abroad.

The purpose of the research reported here was to evaluate the impact of the Act on the UK market and its role in the international illicit market. The first phase of the research was a postal survey which targeted the 89 people and institutions we identified as being significant informants in relation to London's antiquities market. The survey achieved a response rate of 24 , which therefore represents about a quarter of the London market and its attendant spectators, commentators and regulators as we had originally identified them.

In the second phase of the research, interviews were conducted with targeted key respondents in London, Oxford, Cambridge, Cairo and Bangkok. The total number of interviews was 38. The interviews were qualitative in method, meaning that their goal was less to elicit quantifiable data than to gain, in an interpretive vein, 
insight into what the 2003 Act means to actors "on the ground." We can provide a general breakdown of the actors we interviewed, as follows:

- Five dealers from a selection of the most prominent dealerships in London;

- Five "specialists" with expertise in observing, researching and commenting on the illicit market;

- Three specialist law enforcement representatives, including a private investigator, a member of the Metropolitan Police's Art and Antiquities Squad, and a specialist from customs;

- Four respondents in senior positions drawn from the UK's museums sector, including prestigious museums, their major funding sources and associations established to provide collaborative spaces for discussions of matters of museum governance;

- Two key actors in the legislative process who played central influential roles in the design and/or passage into force of the 2003 Act;

- Five respondents in Thailand, including a senior figure in the National Museum, a senior figure in the legal arm of the Fine Arts Department, a dealer and two archaeologists (one local, one foreign);

- Thirteen respondents in Egypt, including senior representatives of the Supreme Council of Antiquities, foreign and local archaeologists, specialist academics and a senior representative of the Egyptian museum.

\section{THE SURVEY DATA}

The survey produced the following data:

\section{Respondents}

What was the balance of trade/non-trade response to the survey? The survey was designed to be filled out anonymously if the respondent so desired, with the result that we cannot categorise respondents in this way unless they identified themselves on the form or otherwise made clear their affiliation in their answers. In fact, the vast majority of respondents were identifiable in this way. Therefore we can say that 58 per cent of respondents were definitely from the trade, 29 per cent were not (ie they fell into the categories of regulators, commentators, archaeologists and other specialists), and in respect of the rest (13\%) affiliation is unknown.

\section{Self-regulation}

Seventy five per sent of respondents thought the trade required formal regulation, and that self-regulation was not adequate to prevent the purchase of illicit antiquities by the trade. This is against 25 per cent who thought that the trade could effectively self-regulate.

\section{Knowledge of the 2003 Act}

Seventy one per cent of respondents reported familiarity with the requirements of the 2003 Act; 17 per cent reported no such familiarity and 12 per cent did not answer this question on the survey.

\section{Effect of the 2003 Act}

Asked if they thought the impact of the Act on the trade in antiquities in London "has been or will be positive or negative", the majority of answers were neither. Seventeen per cent thought the effect positive only, and 8 per cent thought it negative only. Twelve point five per cent thought the effect to be both positive and negative, while the greatest proportion, 29 per cent of respondents, declined to answer the question as it was put but instead wrote that they thought the Act had been and/or would be "neutral", "minimal" or "little" in its effect, or would be "ineffective."

\section{Perceived change in market}

Asked whether they had noticed a change in the way dealers operate as a result of the Act, 50 per cent of respondents said they had seen no change, 21 per cent said they had noticed a change, and 29 per cent did not respond. The 21 per cent that had noticed change represents five responses, of which one suggested any change noticed was "purely cosmetic" and had in effect driven the market "more underground or more under the counter than it was before", one simply noted that the Art Newspaper had reported a small number of dealers relocating abroad, and another claimed to perceive "less activity" in the market due to "despondency." None of these responses would seem to accord with the aims of the 2003 Act. "Purely cosmetic" adaptation, dealer relocation and "despondency" have occurred precisely because a characterisation of the trade as bifurcated between "legitimate" and "illegitimate" dealers is in error. Illegitimate objects pass through the "legitmate" trade and therefore any regulatory attention paid to such objects will, rather than support "legitimate" dealers by eliminating their "illegitimate" peers, directly affect the business of the trade generally.

However, the Act appears to have been ineffective in achieving any substantial effect on the trade: the most important finding here for an evaluation of the Act is that half of respondents, and a significant majority of those who responded to this specific question, had seen no change in market routines as a result of the passage of the Act.

\section{Change in personal routines}

This question was asked only to trade respondents. Asked whether their knowledge of the Act had affected the way they carried on business, or whether it would in the future, 64 per cent said no, 22 per cent said yes (although in some cases only "formal" change was planned), and 
there was 14 per cent non-response. The detail of these responses is important to understand their character within this statistical distribution. The majority "no change" group generally saw no reason to change their routines which they saw to be adequate to constitute legitimate dealing and therefore most unlikely to trigger an offence under the 2003 Act. That the majority of traders surveyed have not and do not intend to alter their activities in light of the Act must be seen to be a significant failing of the legislation unless the "bad apples" market story is believed.

There is considerable evidence that there are bad apples in the antiquities trade, as there are in any business enterprise, in the sense of individuals or organisations who willingly break the law or violate social or moral norms of behaviour. There is also, however, considerable evidence that the problem of dealing in illicit antiquities is an issue that affects the "legitimate" trade insofar as looted antiquities are bought and sold as part of the general routine dealing activity of the open trade, often it seems without direct knowledge of the illicit nature of an object due to a lack of provenance information. The absence of thorough and effective provenance investigation has become routinised in the trade, in the UK as elsewhere, and as such in some deals made on the "legitimate" market, illicit objects are traded with no direct knowledge as to whether they have been looted or not. Importantly, although perhaps obviously, this means that these objects could have been looted.

\section{Bad apples}

There was no specific question asking whether respondents were of the opinion that problems relating to looted antiquities in the trade were the work of a perceived minority of "bad apples" or whether the problem infected the trade as a whole. However, responses to the survey questions are noteworthy in that 25 per cent of respondents (6 in number) attributed problems in the trade to "bad apples", suggesting that a small sector of the trade was untrustworthy and should not be associated with the legitimate trade. Of these six respondents, five were from the trade. Thus, 36 per cent of the trade respondents associated the problem of looting with "bad apples" without being prompted by a specific question to that effect. Given that this response was unprompted, we suggest that the "bad apples" opinion carries significant weight in a diagnosis of the trade's relationship with the looting problem. In keeping with previous research, we suggest that this represents a somewhat pious and complacent view on the part of dealers who may well themselves be dealing in illicit antiquities, perhaps unwittingly.

\section{THE INTERVIEW DATA}

The conceptual starting point for an analysis of the data is the market reduction model of crime reduction strategy in relation to markets in illicit commodities as developed by Mike Sutton and colleagues and published by the Policing and Reducing Crime Unit at the Home Office. The 2003 Act on the face of it would seem to fit with a market reduction philosophy: in a simplified model of the movement of goods from source to market, that criminal sanctions applied to the purchase of illicit material in the market will reduce the uptake of such purchase opportunities; that this reduction in sales will filter back to the "suppliers" of the market, the middle-men; and that the reduction of demand among the customers of these middlemarket traders will result in a concomitant reduction in their demand for illicit antiquities from the looters who take objects from the ground in source countries.

The market reduction approach (MRA) also acknowledges the structural parameters within which certain property crimes occur, for example the "strain" experienced by consumers who cannot afford products heavily advertised as fashionable or otherwise desirable. Sensibly, the model proposes that attending to the provision of alternative legitimate routes to the realisation of these goals for individuals or businesses will reduce the incentive to find or accept illegal means of goalsatisfaction. This might be characterised as a "harm reduction" component to the regulation of illicit markets and can be seen to form a complement in the model to the more traditional "penal deterrence" component outlined above and which, in our analysis, informs the 2003 Act.

The translation of the MRA model to the antiquities market is problematic, however. In a market which functions without the serious transmission of provenance (ie information about the history of ownership of an object), illicit dealing is seen as a standard risk, and remains so despite the creation of the offence in the 2003 Act. Dealers, in other words, are not deterred by virtue of the new legislation:

$$
\begin{aligned}
& \text { "So, stolen goods, yes, they must be here. Possibly over the } \\
& \text { course of time } 10 \text { per cent of my stock has probably been } \\
& \text { stolen at one time or another...I don't know, but it would } \\
& \text { not surprise me if it was that high...either stolen in China, or } \\
& \text { wherever, you just don't know" (London dealer). }
\end{aligned}
$$

The 2003 Act is perceived by dealers and regulators alike as an ineffective control mechanism. A law enforcement respondent put it pithily: "they passed a dead duck there." We can identify the failings of the 2003 Act in terms of a series of "problems" which are given clear form by the data, and which come together to undermine the impact of the legislation. These are the problems of:

1. proof;

2. national self interest and political will;

3. how the 2003 Act fits into the overall structure of regulation of antiquities dealing in the UK;

4. power. 
I cannot address each of these problems here in any great depth, but interested readers might like to obtain a copy of the full research report in respect of this project, which will be made available on the Scottish Centre for Crime and Justice Research website at www.sccjr.ac.uk.

\section{The problem of proof}

The problem of proof in relation to the 2003 Act arises in relation to three related matters:

\section{(a) The non-retroactivity of the operative provisions of the Act}

The 2003 Act came into force on December 30, 2003. It is not retroactive and therefore a "tainted" object is only such if it has been stolen after that date. This clearly restricts the application of the Act in respect of objects already in circulation in the market on that date. More seriously, in any successful prosecution it must be proven that the object in question was stolen after the above date. This perpetuates a problem of proof that existed for prosecutors under the law prior to 2003. The sites from which antiquities are stolen are often isolated, their contents are known only to the finders, and they cross national borders without being recognised or recorded. In these circumstances, it is very difficult indeed to establish proof of the date of theft of an object which has appeared on the market without accurate accompanying information relating to its date of finding.

\section{(b) The absence of provision for enforcement of breach of foreign export prohibition}

Objects which have been exported in breach of a foreign export restriction are not included in the definition of "tainted" under the 2003 Act and as such a considerable proportion of illicit antiquities are excluded from its scope. This could have been an effective site of intervention into the illicit market for the 2003 Act had it been decided to follow examples of international illicit market regulation for other commodities, such as the CITES regulation of the international movement of protected wildlife, which encourage countries to sight export documentation from source before allowing import. The opportunity to tie import into the UK with licit export overseas was not taken for antiquities however.

\section{(c) The difficulty of availability of evidence in relation to the central "knowing or believing" provision}

Proving that a defendant was aware, to the extent of "knowing or believing", that an object he or she dealt in was tainted, in practical terms renders unworkable the offence the Act creates. At the same time this wording serves to undermine the basic message that unites all critics of the market: that effective due diligence in relation to object provenance needs to become an essential component of any purchase of antiquities.
The problem of national self-interest and political will

The 2003 Act is designed to play a role in the control of London's part in the international market in illicit antiquities. As London is a central market for the sale of antiquities which originate, and in some cases have been stolen from, overseas, this mission involves the acceptance by the UK government of a role in policing crimes which predominantly affect the interests of foreign powers. In fact, the idea of the protection of the interests of humanity generally - "the world's history", "our common cultural heritage" and other such emotive terminology - is lost in the practical implementation of a system of resource prioritisation which inevitably occurs in the routine conduct of policing in the context of limited funding and manpower.

The problem of national self-interest does not only manifest itself in relation to the priorities of market countries like the UK. Source countries have a reputation for similar stubborn insularity in addressing the problem of the looting of artefacts within their jurisdiction and their export. This source "nationalism" has been criticised as exacerbating the problem of the illicit market by encouraging the creation of a black market in looted antiquities as a result of overbearing source country excavation laws and export controls. Our interviews in Thailand and Egypt confirm the existence of "nationalistic" retentive attitudes towards cultural property in these source countries. This may well be considered rather normal insofar as pride in a national cultural heritage and the desire to prevent the theft and national loss-through-export of that heritage might be considered sensible, natural "sovereign emotions" which any country's more culturally-sensitive inhabitants and governors might be expected to feel. Unfortunately, despite the seeming reasonableness of such national interest, our research supports the "black market" theory: that harsh controls at source create pressure for illicit export where market demand externally remains constant.

\section{The problem of how the 2003 Act fits into the overall structure of regulation of antiquities dealing, import and export in the $\mathrm{UK}$}

This problem incorporates elements of the problem of proof above. The problem of proof is severe, and when the 2003 Act is held alongside other avenues of prosecution, which permit of a greater chance of success in court, the offence in the 2003 Act finds itself languishing at the bottom of the toolbox available to the police, the CPS and customs. Thus, there have been no concluded prosecutions in terms of the offence in the 2003 Act.

\section{The problem of power}

At issue here is the capacity "powerful" constituencies have to protect their interests. In our study, the powerful constituency is the antiquities market, including some 
museums and collectors, but particularly comprised of a core of active dealers and their lawyers. This group has managed to achieve such a high level of representation in official circles that their interests have become fused with the more "controlling" elements of the 2003 Act. Market interests were in fact in considerable degree constitutive of the 2003 Act, and in this way a picture emerges of a market taking a leading role in its own regulation. This is not selfregulation, however. Rather it is a form of legislative influence corrosive of the regulatory mechanism; a purposive and forceful watering-down of the laws that govern a certain market sector through a process of inclusion in discussions around appropriate levels of control at the time the law was drafted.

\section{Positive effects of the 2003 Act}

The data are not uniformly dismissive of the effect of the 2003 Act, however. Despite the lack of prosecutions and the other problems, theoretical and practical, with the Act listed above, there is evidence that some members of the trade have been affected by the new legislation.

Generally, the reaction from the trade which we have distilled from our interviews and our observations of the market more generally has been one of a cautious and more reflexive "business as usual." As one of our specialist informants euphemistically put it: "the impact of the Act is not instantly evident!” Dealers generally appear to engage in the same transaction routines as before the implementation of the 2003 Act, encouraged by the general (accurate) perception of a culture of nonenforcement around the new legislation. They remain conscious that at this relatively early stage in the aftermath of legislative activity this period of non-enforcement might come to an end, but we might hypothesise that the longer the period of enforcement inactivity continues, the more confident the market will become in the permanence of this state of affairs and the more likely it is that old dealer routines will persist.

That said, some dealers have reportedly begun to implement changes in their patterns of dealing as a result of the 2003 Act. One dealer in our sample in particular asserted that he was taking the new legislation very seriously and that his office had "cut down dramatically on things we buy from Hong Kong." In criminological terms, this reaction might be interpreted as the self-control of an individual particularly susceptible to criminal justice deterrence.

Dealer: You mean, why am I self policing in this manner?

Interviewer: Yes.

Dealer: Well, I just think that the law...I mean, the general view in the trade is that the law is difficult to enforce and a bit toothless....although obviously the penalties are quite large, essentially. My own view is that laws might start off like that, but you never know, they might change one day! You just need a couple of zealots to go around trying to enforce it and the whole aspect of it changes quite rapidly. I don't like the idea of dealing with that sword of Damocles hanging over my head.

It would be mistaken, on our reading of the market, to take this extreme self-policing as common among market actors, although some level of self-policing is characteristic of the "semi-conscious state of siege" (London dealer) which typifies the current market reaction to the new Act.

Perhaps the most important latent potential the Act has is its cumulative effect. Problems of drafting and other issues with the practical workability of the legislation as it stands aside, the problem of non-retroactivity becomes less of a restraint to prosecution as time passes. It is harder to break the law put in place by the 2003 Act now than it will be in five years time, simply due to the increased number of objects which will be excavated in that time, and therefore which will fall foul of the Act. However, in the absence of mechanisms of object provenance identification it will remain very difficult to prove date of excavation.

\section{Implications for policy}

The MRA works where buyers of stolen goods feel that they are under a level of law enforcement scrutiny such that an illegal purchase will have adverse consequences for them. Deterrence theory traditionally has comprised of three elements: certainty (that is, likelihood of being caught); celerity (that is, swiftness of punishment); and severity (that is, a punishment of a level that is thought sufficient to provide a disincentive to law-breaking). The offence in the 2003 Act has failed to have a market reduction effect because although it may satisfy the severity test - and possibly the celerity test although without cases to study this is difficult to say - it falls down on the most basic premise of deterrence; likelihood of detection and punishment. The dealers in our sample were well aware that the police are largely unable to detect the crime of dealing in tainted cultural objects, for the several reasons set out in our research report and adverted to here.

Rather than attempting to close down the antiquities market by means of criminal deterrence targeted at illicit dealing, another option might involve working towards a compromise between the market and source countries. This would involve a shift in the weight attached to internal components of the MRA. The MRA component currently prioritised in UK policy approaches to the market, and embodied in the 2003 Act is punishment-based deterrence, focused on market purchase. In addition to the penal component of the MRA - which focuses on reducing the number of stolen goods passing into a market - is the desire of the MRA model to attend to structural "strains" which underpin stolen goods markets. Thus we might consider mechanisms to legitimate the goods passing into 
the market; maintaining the market while reducing the damage it causes. This is a "harm reduction" approach to stolen goods markets which asks "what is the harm that this market causes, and what can we do about it?"

In the antiquities market the damage caused by looting is predominantly to the archaeological record, and secondarily to the financial interest of source countries in their heritage. Several examples of schemes for the sponsored excavation, cataloguing, division and sale of antiquities have been practised over the years, and many market participants support the idea of such schemes, which are said to involve benefit for all: for archaeologists who conduct the digs and can gather their data; the market which receives a share of the finds (in some models in return for sponsorship); and the source state which exercises control over proceedings and decides which objects to release to the market and which to retain. The suggestion that these schemes may provide a panacea for the current problems in the antiquities market often meets with disapproval from archaeologists, however, who argue that (amongst other things) legitimating a section of the market will not discourage illicit dealing, and may indeed provide opportunity and motive for greater illicit activity. There are in fact many serious objections to such a model of market sanitization, and clearly the application of a harm-reduction strategy through this mechanism is problematic on many fronts. Yet the structure of regulation we have now is not working, and further thought about alternative models of engagement with the problem remains a useful activity.
The regulation of the international market in antiquities does not have to be a zero sum game, and to achieve the mutual benefits which can occur from market reconstruction, a shift in the philosophy of the UK's intervention is required so that the structural dictates of the MRA model are given due weight alongside its more penal dictates. International co-operation towards worthwhile harm-reduction approaches, combined always with an effective deterrent for dealing outside any such cooperative schemes as are erected or revived, appears a more productive route to market sanitization than the bare implementation of the penal part of the MRA model which currently informs the philosophy of UK intervention into the market. It is hoped that the Department of Culture, Media and Sport will turn its attention to exploring possibilities for such international collaborative approaches, rather than investing further in the “crackdown' approach which has been shown here to be so problematic. In respect of what precise form a harmreduction model for the antiquities market might take, further research is needed.

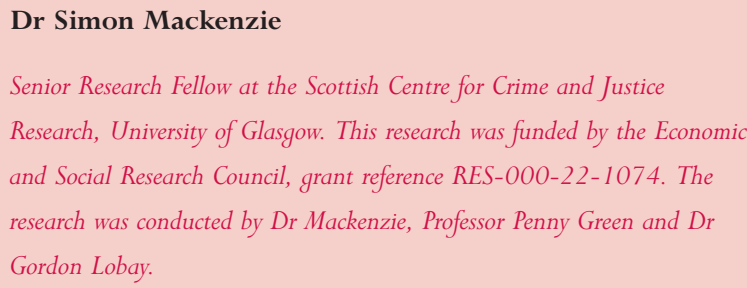

\section{Institute News}

\section{European Commission funds summer course in EU law, institutions and drafting}

The IALS has received funding from the European Commission to offer a summer course in EU law, institutions and drafting for EU membership and accession. The course will be offered in the summer of 2008 to postgraduate students from the EU, and is funded by the Jean Monnet programme of the European Commission.

\section{MA in taxation to be offered next year}

A new masters programme in taxation is to be launched by the IALS for 2008-09.

The MA in taxation (law, administration and practice) is a brand new degree in the context of the University of London and, with one exception, a totally new degree in the UK. The programme aims to give an opportunity for those who are already devoting, or intending to devote, their professional lives to the field of taxation to study the topic from an academic perspective. It is likely to attract students with first degrees in a range of disciplines and will complement the ongoing teaching of taxation in the new, college-based LLM degrees.

\section{Report says Public Defender Service provides vital protection}

The results of a major, independent evaluation of the Public Defender Service (PDS) in England and Wales were published on July 31 by The Stationery Office.

The research was conducted by a team consisting of Professors Lee Bridges of the University of Warwick; Ed Cape of the University of the West of England; Richard Moorhead of the University of Cardiff; and Avrom Sherr of the Institute of Advanced Legal Studies. Professor Bridges, who led the research team, said: 